\title{
Patrons of Maori Culture: Power, Theory and Ideology in the Maori Renaissance
}

\author{
Reviewed by Giselle Byrnes, Victoria University, Wellington
}

\author{
Patrons of Maori Culture: Power, Theory and Ideology in the Maori \\ Renaissance. \\ Steven Webster \\ Dunedin: University of Otago Press, 1998.
}

Steven Webster's Patrons of Maori Culture: Power. Theory and Ideology in the Maori Renaissanceis a collection of essays which addresses two main issues: the place of Maori culture in New Zealand and the scholarly use of the anthropological notion of 'culture'. Webster argues that since the 1960s students of Maori culture-and some Maori-have focused on 'traditional' culture rather than everyday contemporary Maori culture. The ideological separation between the two is the central problem he addresses. Patrons of Maori Culture is divided into three sections: 'culture', 'history' and 'university'. In his opening chapter Webster considers modern Maori culture, arguing that the assumption that 'Maori culture' refers to a whole way of life is largely ideological, in that it obscures that other part of Maori culture which is all about struggle and survival. Chapter two examines Maori and the people of Rapanui (Easter Island) and the way in which they make sense of their own 'fragmented' cultures through the image of the other. The next three chapters are grouped under the general heading of 'history'. Chapter three looks at the roots of Maoritanga in the political and economic climate of New Zealand during the 1920s and the anthropological ideas which were being developed at that time. In chapter four Webster considers the work of Ralph Piddington, the founder of modern social anthropology in New Zealand, arguing that despite Piddington's many positive efforts, he nonetheless helped to create a notion of 'culture' as traditional whole ways of life which were considered outside their own history. Chapter five presents a critical review of the last thirty years of the academic discipline of 'Maori Studies'. The final three chapters focus on Maori culture and its 'patrons' at the university of Auckland. Chapter six chronicles the development of Maori Studies at the University of Auckland since 1972. Chapter seven describes the creation of marae art and 'the reproduction of Maori ethnicity'. The final chapter considers the postmodernisation of Maori culture, or as Webster describes 'the appropriation of Maori culture as a whole way of life, to the disregard of its other

Kōtare 2, no. 2 (1999), pp. 71-73. 
side, by theoretical interests stemming from the French post-structuralist development of meanings-based cultural theory' (255).

The title of this book is a deliberate play on Ruth Benedict's 1930's publication Patterns of Culture. Webster, who teaches in the Department of Anthropology at the University of Auckland, claims that his method is 'ethnographic', which he defines as 'the written description and analysis of another culture, understood through the anthropological method of participant observation' (7). Webster, the self-defined 'participant ethnographer', makes it clear throughout that he is a white male American academic. This is important because so much of his argument is based on his own observations, within the context of the university. He is clearly opposed to what he considers to be an alliance between the university and the business interests, most notably the neo-liberal restructuring of the state. Webster's contempt for market-driven philosophy is only rivalled by his suspicion of literary postmodernism, as expressed by certain members of the Department of English at the University of Auckland. The 'Maori Renaissance' of the title he sees as the 'ethnic mobilisation' which had started in the early 1970s. Some historians may well find this term highly problematic, given that Maori have, for the last 150 years at least, petitioned for land grievances and called for greater recognition of their culture.

Those readers who are already familiar with Webster's work will find little that is new in this volume, as versions of five of the eight chapters have been previously published elsewhere. The main questions of this book are important but remained only partially answered: what is the relationship between the (socalled) Maori Renaissance to social impoverishment more generally in Maori society? And, whose definition of Maori culture is being promoted and in what context? While this book has its problems, it does nonetheless present a challenging thesis. However, this reviewer is left wondering just how, in publishing this book, Webster can distance himself from the 'patrons' of whom he is so critical?

Kōtare 2, no. 2 (1999), pp. 71-73. 